\title{
Analysis of Factor's Causing Delays in Road Project by Severity Index Method
}

\author{
Shubham Ashok Avhad, Satish M. Waysal
}

\begin{abstract}
The construction sector is one of the important sources of growth and development of the national economy. However, entirely projects background delays in construction work and therefore raise its time and money. Problem in structure/construction work is studied one of the important obstacles in the work and it has a very large issue in terms of time, money, and quality. This survey is done to find the time achievement of the road development project to identify the causes of delays and related factors according to the contractor with the help of the Questionnaire Survey which was taken with the help of Google Forms. As per the research, there are a total of 32 factors affecting the delay/ failure of the road. As per the survey accidents during construction, an increase in material price, change in cost, and delay in time are the top factors which mostly affect the road failure. These factors were analyzed with the help of the Severity Index Method and mathematically with the help of Excel and Google Forms and then the result was calculated.
\end{abstract}

Keywords: Delay, Management, Severity Index, Road Failure, Quality.

\section{INTRODUCTION:}

The management of construction is very much important factor by which the country bring about its goal of development of agrarian as well as in urban areas in the nation. It has a high effect on the economy of the nation. It is the only field that provides great ingredients for the enhancing higher complicated because of the planning process as well as a huge number of different parties are convoluted in the construction operation, i.e., patient, users, planner, regulators, contractors, suppliers, subcontractors, and advisor. In this survey study, objectives of delay, management, time, and quality are found to calculate whether the project is fortunate/successful or not. Also, the different factors were identified with the help of the Severity Index. Site observations, of road failure in various countries, indicate the frequent occurrence of delays in work. The study of the factors of road failure is advantageous because it gives us the accurate reason for delay and failure which makes the future work easy, the knowledge of delay of work makes more efficient and high accuracy in future work [7]. Several exercises have been done to analyze the provoke of delays in construction activity.

Revised Manuscript Received on October 10, 2020.

* Correspondence Author

Shubham Ashok Avhad*, PG Student, Department of Civil Engineering, NDMVP'S K.B.T. College of Engineering, Nashik, Maharashtra, India.

Satish M. Waysal, Assistant Professor, Department of Civil Engineering, NDMVP'S K.B.T. College of Engineering, Nashik, Maharashtra, India

(C) The Authors. Published by Blue Eyes Intelligence Engineering and Sciences Publication (BEIESP). This is an open access article under the CC BY-NC-ND license (http://creativecommons.org/licenses/by-nc-nd/4.0/) evolution of a recession of the nation. However, it is

As per the study and survey, there are around 32 factors affecting delays in road project failure. Problem causes are distributed into different main groups with contrasting levels of severity and factors. The design of an untrained designer is the most important possible cause of building construction followed by incomplete drawing and coincidence of disaster because of insufficient security procedures. The contractors as well as consultants accept that the holder interference, insufficient contractor participation, financing and payments, labor capacity, deciding, false outlining, and subcontractors are among the highest biggest vital purpose of construction delay. The main purpose of delays was similar to the designer, user changes, climate, site position, slow deliveries, economic conditions, and quantity. Around 73 principal of delay were identified from the study [7]. The most similar cause of detention analyze by the contractors, the consultants, and the owners is "change order". The materials, equipment, as well as labor-related detention, are major causes of 'contractors'. The obstacle of the construction industry in developing economies can also be listed in the following layers: (1) obstacle of lack or inadequacies in the construction industry, primarily supply of resources; (2) obstacle caused by clients and consultants; and (3) obstacles caused by contractors. As per the survey the purpose of delays in the construction industry from the eye aspect of owners, contractors, as well as architectural/engineering firms. It was found that holders had more firms regarding financial problems; and contractors regarded contractual ties as a foremost critical, whereas consultants considered project management problem is the most important causes of delays. The causes of delay, as well as cost overcome in construction projects, show the very bigger causes are financing and payment for incomplete work, lack of contract planning, changes in construction site conditions, lack of materials well as incorrect design. As per the panel discussion, there are different factors of delays and cost overrun related factors affecting the project.

\section{METHODOLOGY:}

This analysis survey depends on a survey draft to collect complete necessary data effectively. From the survey, we found around 32 delay causes generated based on related analysis work on construction delay and according to different factors were separated into different categories. To achieve this purpose of the study a questionnaire was designed to cover the different factors.

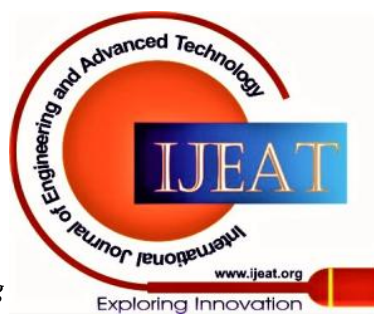

(C) Copyright: All rights reserved. 
A Five Pointer Likert scale from low (1) to high (5) was used for the appraisal of density, with very low (1) to very high (5) assigned for severity [8]. The studied objective population includes consultants and contractors.

The clients are avoided in the questionnaire research because the road development projects are public and funded by the government (the client), meaning that there is only one client and so its view cannot be calculated through a questionnaire or panel discussion. Data were gathered from contractors as well as consultants through a survey and panel discussion and analyzed by using an SI Method. Recommendations for minimizing delays in road project failure were emphasized because of the results of the survey. From the research paper study we found around 52 factors but from the contractors and consultant point of view around 32 factors are affecting the road project failure [8].

\subsection{Questionnaire Design:}

The questionnaire study is a well-known and commonly recommended analysis technique for immediate and accurate collecting and study data. A questionnaire study has been used in just in many fields, e.g., health, industrial relations, construction, transport planning, rural development, and many others. It could be printed both on paper and a computer screen [8].

\subsection{Likert Scale:}

In research on affective variables like motivation, beliefs, and attitudes, we are handling phenomena in mathematics scale type. This 'latent' variable is expressed by several 'manifested' items in the questionnaire. These constructed items under inquiry and in cohesion measure the entire phenomena. During analysis, the many items of the questionnaire are combined (sum) to get a composite score, which logically in totality measures annuli-dimensional trait. This is an instrument known as a Likert scale.

2.3 Severity Index:

The suggested delay causes in the safety of Construction projects are ranked by the measurement of the severity index. The following formula is used to rank the following [8]-

Where

$$
\text { SI }(\%)=\text { Sum of }(a *(n / N) * 100) / 5
$$

$\mathrm{a}=$ constant expressing weighting given to each response which ranges from 0 for very low to 5 for very high, $\mathrm{n}=$ frequency of the response,

$\mathrm{N}=$ total number of responses.

\section{DATA ANALYSIS:}

To study the failure perception of the road project, we have met different contractors. A user's feedback survey was taken out by the contractor. The questionnaire layout is an important step for any approach survey study. The questionnaire design is to be in such a way that it includes all the important volatility related to the objectives of the present study. The questionnaire is based on the following type of information: (1) trip and socioeconomic data and (2) users' perception related data.

The data obtained from the Government Contractor and Private Contractor survey was checked for road construction failure. A total of 11 samples were obtained out of that six samples of Government contractors and five samples of Private Contractors were obtained from the survey. In this, the questionnaire was analyzed by using the Severity Index (SI) Method. SI is used to determine the priority of the various causes and effects of safety. The same method is going too adopted in the study within various groups (i.e. physical safety, physical injuries, job stress, fire safety, safety meeting, and health safety. The five-pointer scale ranged from 1 (less influencing) to 5 (more influencing) will be used and will be transformed to SI for each factor as follows:

Where

$$
\text { SI }(\%)=\text { Sum of }(a *(n / N) * 100) / 5
$$

$\mathrm{a}=$ constant expressing weighting given to each response which ranges from 0 for very low to 5 for very high,

$\mathrm{n}=$ frequency of the response,

$\mathrm{N}=$ total number of responses.

Table 1: Severity Index Scale and Corresponding Impact Factor [8]

\begin{tabular}{|c|c|}
\hline Severity Index Scale & Impact Factor \\
\hline $0-20$ & Very Low \\
\hline $20-40$ & Low \\
\hline $40-60$ & Moderate \\
\hline $60-80$ & High \\
\hline $80-100$ & Very High \\
\hline
\end{tabular}

Table 2: Average Value of Severity Index for the various causes of Delay's in Road Project

\begin{tabular}{|c|l|c|c|}
\hline Sr. No. & \multicolumn{1}{|c|}{ Factors } & Severity Index (\%) & Average \\
\hline A & PROJECT RELATED FACTOR & & \\
\hline 1 & Blocking of Road Inlet. & 67.8 & \\
\hline 2 & Overgrowth of pipe, culvert inlet. & 65.08 & \multirow{2}{*}{$\mathbf{6 2 . 1 6}$} \\
\hline 3 & Insufficient diameter of pipe. & 62.71 & \\
\hline 4 & Mechanical damage of pipe. & 61.02 & \\
\hline
\end{tabular}




\begin{tabular}{|c|c|c|c|}
\hline 5 & Large water flow in the pipe. & 62.2 & \\
\hline 6 & Landslide. & 60.51 & \\
\hline 7 & Soil damage / Poor soil quality. & 65.76 & \\
\hline 8 & Frost action damage. & 58.14 & \\
\hline 9 & Agriculture Land. & 64.75 & \\
\hline 10 & Forestry land. & 62.54 & \\
\hline 11 & Cables or pipes provided under the ground. & 63.22 & \\
\hline $\mathbf{B}$ & OWNER RELATED FACTOR & & \\
\hline 12 & Poor communication. & 64.24 & \multirow{3}{*}{63.50} \\
\hline 13 & Delay in decision making. & 65.76 & \\
\hline 14 & Delay in payment by the owner. & 60.51 & \\
\hline $\mathbf{C}$ & MATERIALS AND EQUIPMENTS RELATED FACTORS & & \\
\hline 15 & Change in Cost. & 61.86 & \multirow{5}{*}{60.75} \\
\hline 16 & Delay in Time. & 61.69 & \\
\hline 17 & Shortage of materials. & 58.31 & \\
\hline 18 & Increase in material price. & 57.29 & \\
\hline 19 & Shortage of Equipment. & 64.58 & \\
\hline $\mathbf{D}$ & LABOR RELATED FACTOR & & \\
\hline 20 & A large number of workers as compared to require on-site. & 64.07 & \multirow{2}{*}{63.82} \\
\hline 21 & Unskilled Equipment operator. & 63.56 & \\
\hline $\mathbf{E}$ & EXTERNAL RELATED FACTOR & & \\
\hline 22 & Change in Climate. & 64.24 & \multirow{6}{*}{62.49} \\
\hline 23 & Unstable political situation. & 61.19 & \\
\hline 24 & Limited construction area. & 66.27 & \\
\hline 25 & Accidents during construction. & 60 & \\
\hline 26 & Change in the policy of the donor country. & 61.19 & \\
\hline 27 & Working during Rainy season. & 62.03 & \\
\hline $\mathbf{F}$ & DESIGN RELATED FACTOR & & \\
\hline 28 & Failure of Quality. & 66.27 & \multirow{5}{*}{62.34} \\
\hline 29 & Late Design work. & 65.25 & \\
\hline 30 & Mistake or Error in design. & 59.49 & \\
\hline 31 & Poor Site Management & 60 & \\
\hline 32 & Rework due to the bad quality. & 60.68 & \\
\hline
\end{tabular}

IV. 
Following Fig1 shows the average value of different Main Groups used in the survey. All the values are in percentage (\%).

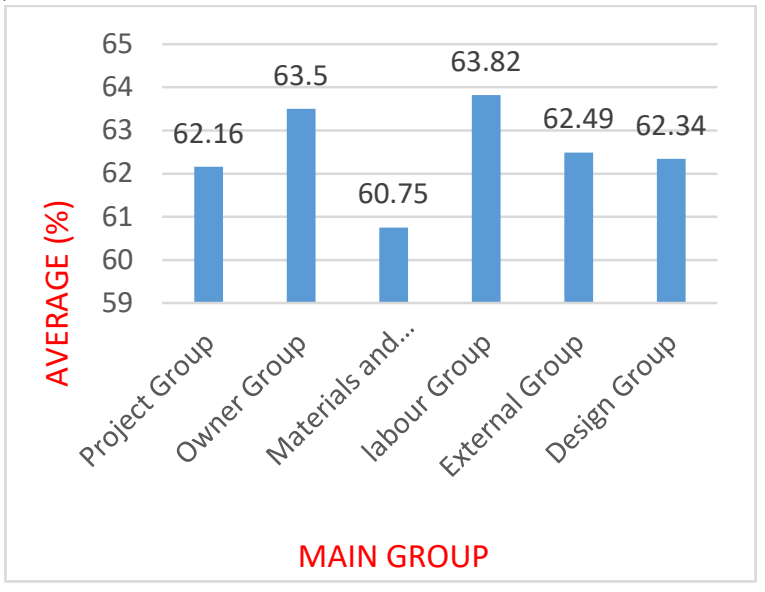

Fig.1 Average value of the Main Group

As per the data collected and analyzed done, there are top most main factors

\section{A. Project Related Factor}

As there are a total of eleven factors in this main group and the average of this main group is $62.16 \%$, and there are around seven factors whose SI value is more than the average value of the main group. The top factors of this main group are an overgrowth of pipe, culvert inlet (65.08\%), insufficient diameter of pipe (62.71\%), large water flow in a pipe (62.20), soil damage, poor soil quality (65.76\%), agriculture land (64.75\%), forestry land $(62.54 \%)$, cables or pipes provided under the ground

\section{B. Owner Related Factor}

As there are a total of three factors in this main group and the average of this main group is $63.50 \%$, and there are around two factors whose SI value is more than the average value of the main group. The top factors of this main group are poor communication (64.24\%), delay in decision making (65.76\%).

\section{Materials and Equipment's Related Factors}

As there are a total of five factors in this main group and the average of this main group is $60.75 \%$, and there are around three factors whose SI value is more than the average value of the main group. The top factors of this main group are change in cost $(61.86 \%)$, delay in time (61.69\%), and shortage of equipment (64.58\%).

\section{Labor Related Factor}

As there are a total of two factors in this main group and the average of this main group is $63.82 \%$, and there is only one factor above the average value of the main group i.e. a large number of workers as compared to require on-site (64.07\%).

\section{E. External Related Factor}

As there are a total of six factors in this main group and the average of this main group is $62.49 \%$, and there are around two factors whose SI value is more than the average value of the main group. The top factors of this main group are (63.22\%).

change in climate (64.24\%) and limited construction area (66.27\%).

\section{F. Design Related Factor}

As there are a total of five factors in this main group and the average of this main group is $62.34 \%$, and there are around two factors whose SI value is more than the average value of the main group. The top factors of this main group are the failure of quality (66.27\%) and late design work (65.25\%). From Table 1 we have categorized the Severity Index into different parts. There is not even a single factor whose percentage is below zero i.e. whose impact factor is low or very low. Factors having Moderate Impact Factor (40\% - 60\%) are Blocking of Road Inlet (57.8\%), Frost action damage (58.14), Shortage of materials (58.31\%), Increase in material price (57.29\%), Accidents during construction (60.00\%), Mistake or Error in design (59.49\%), Poor Site Management (60.00\%). The factors having High Impact Factor (60\% - 80\%) are Overgrowth of pipe, culvert inlet $(65.08 \%)$, the insufficient diameter of the pipe (62.71\%), and Mechanical damage of pipe (61.02\%), Large water flows in the pipe (62.2\%), Landslide (60.51\%), Soil damage / Poor soil quality (65.76\%), Agriculture Land (64.75\%), Forestry land (62.54\%), Cables or pipes provided under the ground (63.22\%), Poor communication (64.24\%), Delay in decision making (65.76\%), Delay in payment by owner (60.51\%), Change in Cost (61.86\%), Delay in Time (61.69\%), Shortage of Equipment's (64.58\%), a Large number of workers as compared to require on site (64.07\%), Unskilled Equipment operator (63.56\%), Change in Climate (64.24\%), Unstable political situation (61.19\%), Limited construction area (66.27\%), Change in the policy of the donor country(61.19\%), Working during Rainy season (62.03\%), Failure of Quality (66.27\%), Late Design work (65.25\%), Rework due to the bad quality (60.68\%). The factors having Very High Impact Level (80\% - 100\%) are zero.

\section{CONCLUSION:}

The delay caused in road projects failure are discussed with the help of panel discussion and questionnaire survey. We studied the various types of causes of delay from the contractor's and consultant's point of view. Through an analysis, 32 causes of delay were classified and it was distributed into six different groups. The panel discussion includes six government contractors and five private contractors. As per the survey the Impact Level of maximum factors is High (60\% to $80 \%)$ and limited factors have Impact Level of Moderate (40\% to $60 \%)$.

\section{REFERENCES}

1. W. F. Lee, A.M.ASCE, H. J. Liao, M.ASCE, M. H. Chang, C. W. Wang, S. Y. Chi, and C. C. Lin, "Failure Analysis of a Highway Dip Slope Slide ", Journal of Performance of Constructed Facilities, ASCE, Vol. 27, pp. 1, 2013.

\section{Published By:}

Blue Eyes Intelligence Engineering 
2. R. P. Chen, Z. C. Li, Y. M. Chen, C. Y. Ou, Q. Hu, and M. Rao, "Failure Investigation at a Collapsed Deep Excavation in Very Sensitive Organic Soft Clay", Journal of Performance of Constructed Facilities, ASCE, December 12, 2013.

3. Yong K. Cho, Thaddaeus Bode, Jongchul Song, and Jin- HoonJeong, "Thermography -Driven Distress Prediction from Hot Mix Asphalt Road Paving Construction", Journal of construction engineering and management, ASCE, Vol. 138, pp. 2, 2012.

4. Byungil Kim, Hyounkyu Lee, Hyungbae Park, and Hyoungkwan Kim4, "Estimation of Greenhouse Gas Emissions from Land-Use Changes due to Road Const in the Republic of Korea", Journal of construction engineering and management, ASCE, Vol. 139, pp. 3, 2013.

5. Steven Vick and IoannisBrilakis, "Road Design Layer Detection in Point Cloud Data for Construction Progress Monitoring", Journal of Computing in Civil Engineering, ASCE, 2018.

6. Fengwen Lai, Fuquan Chen, and Dayong Li, "Bearing Capacity Characteristics and Failure Modes of Low Geosynthetic-Reinforced Embankments Overlying Voids", International Journal of Geomechanics, ASCE, 2018.

7. Zahra Kalantari and Lennart Folkeson, "Road Drainage in Sweden: Current Practice and Suggestions for Adaptation to Climate Change", Journal of Infrastructure Systems, ASCE, Vol. 19, pp. 2, 2013.

8. Ibrahim Mahamid, Amund Bruland and Nabil Dmaidi, "Causes of Delay in Road Construction Projects", Journal of Management in Engineering, ASCE, Vol. 28, pp. 3, 2012.

9. Z. Ren, G. Q. Shen and X. L. Xue, "Failure Caused by Inappropriate Construction Methods: An Expensive Lesson", Journal of Management in Engineering, ASCE, Vol. 29, pp. 1, 2013.

10. Djoen San Santoso, Ph.D., and SothySoeng, "Analyzing Delays of Road Construction Projects in Cambodia: Causes and Effects", Journal of Management in Engineering, ASCE, 2016.

11. Feng Li, Ph.D., A.M.ASCE, Hui Li, Ph.D., P.E., M.ASCE, and Tinggang Li, Ph.D., "Evaluation of Premature Failures of Asphalt Pavement Crack Sealing Bands", Journal of Materials in Civil Engineering, ASCE, 2015.

12. Earl Marvin B. De Guzman, S.M.ASCE, and Marolo C. Alfaro, Ph.D., P.Eng., "Geotechnical Properties of Fibrous and Amorphous Peats for the Construction of Road Embankments", Journal of Materials in Civil Engineering, ASCE, 2018.

13. Kristin Svenson, "Estimated Lifetimes of Road Pavements in Sweden Using Time-to-Event Analysis", Journal of Transportation Engineering, ASCE, 2014

14. By Elmar K. Tschegg, Georg Kroyer, Dong-Ming Tan, Stefanie E. Stanzl-Tschegg, and Johann Litzka, "Investigation of Bonding Between Asphalt Layers on Road Construction", Journal of Transportation Engineering, ASCE, Vol. 121, pp.4, 1995.

15. By Fabian C. Hadipriono, M. ASCE and Hana- Kwang Wang, "Analysis of Causes of Falsework Failures in Concrete Structures", Journal of Construction Engineering and Management, ASCE, Vol. 112, pp. 1, 1986.

16. R. Navon, M. ASCE, and Y. Shpatnitsky, "Field Experiments in Automated Monitoring of Road Construction", Journal of Construction Engineering and Management, ASCE, Vol. 131, No. 4, 2005.

17. V. K. Quagraine, Ph.D., S. G. Brandenburg, Ph.D., and Y. J. Beliveau, Ph.D., "Improving Labor-Based Road Rehabilitation in Ghana", Journal of Management in Engineering, ASCE, Vol. 25, pp. 2, 2009.

18. By Kenneth L. Carpet, M. ASCE, "Failure Information: Dissemination Strategies", Journal of Performance of Constructed Facilities, ASCE, Vol. 1, pp. 1, 1987.

19. By Kenneth L. Carper, M. ASCE, "Structural Failures During Construction", Journal of Performance of Constructed Facilities, ASCE, Vol. 1, pp. 3, 1987.

20. Raymond S. Rolling and Marian Poindexter Rolling, "Pavement Failures: Oversights, Omissions, and Wishful Thinking", Journal of Performance of Constructed Facilities, ASCE, Vol. 5, pp. 4, 1991.

21. Mohammed S. Hashem M. Mehany, Ph.D., A.M., and Angela Acree Guggemos, Ph.D., A.M., "Risk-Managed Lifecycle Costing for Asphalt Road Construction and Maintenance Projects under Performance-Based Contracts", Journal of Risk and Uncertainty in Engineering Systems, Part A: Civil Engineering, ASCE, 2001.

\section{AUTHORS PROFILE}

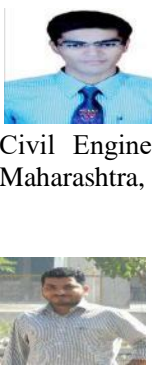

Shubham Ashok Avhad ${ }^{1}$, PG Student,Department of Civil Engineering,NDMVP'S K.B.T. College of Engineering, Nashik, Maharashtra, India.

Satish M. Waysal'2, Assistant Professor,Department of Civil Engineering,NDMVP'S K.B.T. College of Engineering, Nashik, Maharashtra, India

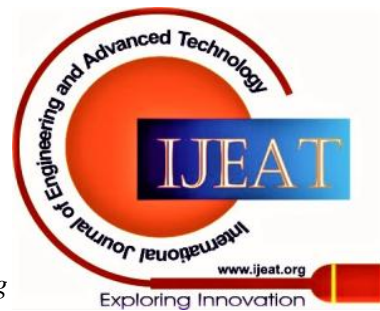

